\title{
PENINGKATAN PEMAHAMAN KONSEP MATEMATIKA SISWA SD KELAS III MEGGUNAKAN PEMBELAJARAN CTL
}

\author{
Melinda Rismawati ${ }^{1}$, Yunista ${ }^{2}$ \\ STKIP Persada Khatulistiwa Sintang ${ }^{1,2}$ \\ e-mail: $\underline{1}$ melris_1@yahoo.com,$\underline{2}$ yunista1096@gmail.com
}

\begin{abstract}
The purpose of this research is to improve the understanding of the concept of multiplication and Division Operations Count on Learners class III C SD Negeri 20 Mambok Year Lessons 2018/2019 using Contextual learning, Teaching and Learning (CTL). This form of research is research that is implemented in the class action two cycles. Each cycle consists of four stages, i.e., planning, implementation, observation, and reflection. The subject was a C class III learners SD Negeri 20 Mambok Year Lessons 2018/2019 totalling 28 people learners. Data source derived from the learners class III C, master class III C, learning events, and documents. Data collecting tool was used, namely the observation sheet (teachers and students), the question of the test, and now the response sheet learners. Study results showed that CTL can increase understanding of Computational Operations multiplication and Division learners. The learning activities of students on a cycle I gained average of $89 \%$ with criteria very well. In cycle II, the results of the activity of the students obtained the average of $94.5 \%$ criteria very well. Understanding the learners on a cycle I and cycle II experienced an increase of 25.92 percent. While the response of the students towards the learning of CTL is very good. The response of the students towards learning by using learning acquired CTL average of $97.2 \%$ of the criteria very well. Based on the research conducted, it was concluded that the application of learning in General CTL can increase understanding of the concept of operations of multiplication and Division Count learners class III C SD Negeri 20 Mambok 2018/2019 Years of Lessons 2018/2019.
\end{abstract}

Keyword: CTL, understanding the concept of Computational Operations, multiplication and Division.

\begin{abstract}
Abstrak. Tujuan penelitian ini adalah untuk meningkatkan Pemahaman Konsep Operasi Hitung Perkalian dan Pembagian pada Siswa Kelas III C SD Negeri 20 Mambok Tahun Pelajaran 2018/2019 menggunakan pembelajaran Contextual Teaching and Learning (CTL). Bentuk penelitian ini adalah penelitian tindakan kelas yang dilaksanakan dalam dua siklus. Tiap siklus terdiri dari empat tahapan, yaitu perencanaan, pelaksanaan, observasi, dan refleksi. Subjek penelitian adalah siswa kelas III C SD Negeri 20 Mambok Tahun Pelajaran 2018/2019 yang berjumlah 28 orang siswa. Sumber data berasal dari siswa kelas III C, guru kelas III C, kegiatan pembelajaran, dan dokumen. Alat pengumpul data yang digunakan yaitu lembar observasi (guru dan siswa), soal tes, dan lembar angket respon siswa. Hasil penelitian menunjukkan bahwa pembelajaran CTL dapat meningkatkan Pemahaman Konsep Operasi Hitung Perkalian dan Pembagian Siswa. Aktivitas belajar siswa pada siklus I diperoleh rerata sebesar $89 \%$ dengan kriteria sangat baik. Pada siklus II hasil aktivitas siswa diperoleh rerata sebesar 94,5\% dengan kriteria sangat baik. Pemahaman konsep siswa pada siklus I dan siklus II mengalami peningkatan sebesar $25,92 \%$. Sedangkan respon siswa terhadap pembelajaran CTL sangat baik. Respon siswa terhadap pembelajaran dengan menggunakan pembelajaran CTL diperoleh rerata sebesar 97,2\% dengan kriteria sangat baik. Berdasarkan penelitian yang dilakukan, disimpulkan secara umum bahwa penerapan pembelajaran CTL dapat meningkatkan Pemahaman Konsep Operasi Hitung Perkalian dan Pembagian siswa kelas III C SDN 20 Mambok Tahun Pelajaran 2018/2019.
\end{abstract}

Kata Kunci: CTL, Pemahaman Konsep, Operasi Hitung Perkalian dan Pembagian. 


\section{PENDAHULUAN}

Matematika merupakan mata pelajaran pokok yang diajarkan pada jenjang pendidikan Sekolah Dasar. Pada mata pelajaran matematika siswa diajarkan berbagai konsep-konsep dasar berhitung, dan perubahan kontekstual ke abstrak. Siswa diajak untuk memahami konsep-konsep dan dalam konteks permasalahan matematika yang dikaitkan dengan kehidupan nyata. Hal ini sejalan dengan pernyataan NCTM (Rismawati, 2017: 465) bahwa materi matematika memiliki koneksi yaitu hubungan antar konsep dalam satu topik yang sama, serta hubungan antar materi dalam topik tertentu dengan materi dalam topik lainnya dalam matematika dan hubungan antara topik matematika dengan kehidupan sehari-hari.

Siswa dikatakan memahami konsep matematis apabila memenuhi indikator, yaitu: 1) Kemampuan menyatakan ulang sebuah konsep; 2) Kemampuan mengklasifikasikan objek menurut sifat-sifat tertentu sesuai dengan konsep; 3) Kemampuan memberi contoh dan bukan contoh; 4) Kemampuan menyajikan konsep dalam berbagai bentuk representasi matematika; 5) Kemampuan mengembangkan syarat perlu atau syarat cukup dari suatu konsep; 6) Kemampuan menggunakan, memanfaatkan dan memilih prosedur tertentu dan 7) Kemampuan mengaplikasikan konsep atau algoritma kepemecahan matematika.

Dari hasil observasi yang peneliti lakukan pada saat pembelajaran matematika di kelas III C SD Negeri 20 Mambok, peneliti menemukan fakta bahwa tidak semua siswa memahami konsep dari operasi perkalian dan pembagian, siswa kurang aktif selama proses pembelajaran, dan guru kurang melibatkan siswa dalam pembelajaran. Imbas dari pemahaman konsep yang kurang menyebabkan siswa mengalami miskonsepsi tentang makna perkalian dan pembagian. Hal ini dibuktikan dengan hasil tes yang diberikan oleh peneliti untuk menggali kemampuan pemahaman konsep matematis siswa. Setelah peneliti menganalisis hasil pekerjaan siswa diperoleh fakta bahwa dari 32 peserta didik hanya 14 peserta didik yang memperoleh nilai sesuai dengan Kriteria Ketuntasan Minimal (KKM) yang sudah ditentukan di SD Negeri 20 Mambok yaitu 65 atau sekitar $44 \%$. Berikut adalah contoh hasil pekerjaan siswa.

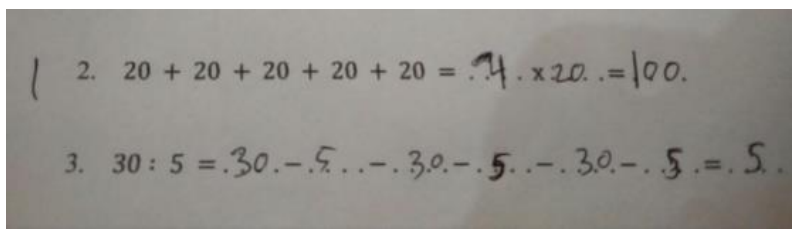

\section{Gambar 1 Contoh Hasil Pekerjaan Siswa}

Dari Gambar 1 memperlihatkan bahwa jawaban siswa tidak sesuai dengan konsep pembagian. Jawaban yang diharapkan adalah $30: 5=30-5-5-5-5-5-5=0$,
$30: 5=6$. Tetapi pada kenyataannya jawaban dari sebagian peserta didik tidak sesuai harapan. Salah satu jawaban peserta didik yaitu $30: 5=$ $30-5-30-5-30-5-5=5$. 
Kesalahan yang dialami oleh peserta didik tersebut adalah peserta didik tidak memahami makna konsep pembagian. Pembagian adalah pengurangan berulang. Bilangan yang berulang adalah bilangan pembaginya bukan bilangan yang membagi. Apabila, permasalahan di atas jika tidak segera ditangani, maka proses belajar mengajar akan kurang efektif akhirnya mempengaruhi tingkat prestasi belajar matematika peserta didik secara berkelanjutan.

Agar kemampuan pemahaman konsep matematis siswa berkembang secara optimal, siswa harus diberi kesempatan untuk mengkonstruksi pengetahuannya sendiri dengan cara mengaitkan pengetahuan yang dipelajari dengan dunia nyata (mathematical connection/ koneksi matematika). Hal ini sejalan dengan NCTM (Rismawati, 2016: 127) mengatakan bahwa koneksi matematis (mathematical connection) merupakan salah satu standar yang bertujuan untuk membantu pembentukan persepsi siswa dengan cara melihat matematika sebagai bagian terintegrasi dengan dunia nyata dan mengenal manfaat matematika baik di dalam maupun di luar sekolah. Pada proses pembelajaran, guru dituntut untuk dapat menggunakan model pembelajaran matematika yang dapat menggali dan meningkatkan pemahaman konsep siswa, sehingga membuat pembelajaran matematika lebih menyenangkan dan siswa dapat menguasai materi dengan baik. Salah satu cara untuk mengatasi masalah tersebut yaitu dengan menggunakan pembelajaran Contextual Teaching and Learning (CTL), dimama siswa diharapkan belajar melalui pengalaman bukan menghafal.
Sanjaya (2011:255) menjelaskan CTL adalah pembelajaran yang menekankan kepada proses keterlibatan siswa secara penuh untuk dapat menemukan materi yang dipelajari dan menghubungkannya dengan situasi kehidupan nyata sehingga mendorong siswa untuk dapat menerapkannya dalam kehidupan siswa. Pembelajaran dengan pendekatan CTL melibatkan tujuh komponen utama yaitu (1) constructivism (konstruktivisme, membangun, membentuk), (2) questioning (bertanya), (3) inquirí (menyelidiki, menemukan), (4) learning community (masyarakat belajar), (5) modelling (pemodelan), (6) reflection (refleksi atau umpan balik), dan (7) authentic assessment (penilaian yang sebenarnya).

Wulan (2013: 8) mengemukakan keunggulan penerapan pendekatan CTL : (1) Real world learning yaitu pembelajaran dikaitkan dengan kehidupan nyata dan masalah yang disimulasikan dalam pembelajaran. (2) Mengutamakan pengalaman dalam kehidupan nyata siswa, yaitu menghubungkan materi yang sedang dipelajari dengan pengalaman yang dimiliki siswa. (3) Proses berfikir tingkat tinggi, siswa dituntut untuk menggali pengetahuan secara kreatif untuk mengumpulkan informasi sebanyak mungkin dan mencari suatu pemecahan suatu masalah. (4) Student centered yaitu berpusat pada siswa bukan teacher centered atau berpusat pada guru. Sehingga siswa lebih mendominasi pembelajaran lebih banyak terlibat dalam setiap proses. (5) Siswa aktif, kritis dan kreatif maksudnya siswa menggunakan kemampuan berfikir kritis, terlibat penuh dalam proses pembelajaran yang 
efektif. (6) Realistis, dekat dengan kehidupan nyata siswa sehingga pembelajaran lebih nyata dengan media yang ada di sekitar lingkungan siswa.

Berdasarkan masalah tersebut peneliti melakukan penelitian tindakan kelas untuk meningkatkan pemahaman konsep operasi hitung perkalian dan pembagian pada siswa kelas III C SD Negeri 20 Mambok Tahun Pelajaran 2018/2019 menggunakan pembelajaran CTL.

\section{METODE}

Metode yang digunakan dalam penelitian ini adalah metode penelitian kualitatif. Metode penelitian kualitatif merupakan metode penelitian yang berlandaskan pada filsafat postpositivisme, digunakan untuk meneliti pada kondisi obyek alamiah. Menurut Sugiyono (2014: 17) 'Dalam penelitian kualitatif yang berlandaskan pada filsafat postpositivisme atau paradigma interpretive, suatu realitas atau obyek tidak dapat dilihat secara parsial dan dipecah kedalam beberapa variabel'. Penelitian ini berbentuk penelitian tindakan kelas (Class Action research). Penelitian ini dilaksanakan dalam dua siklus, setiap siklusnya terdiri dari indentifikasi masalah yang dihadapi oleh guru, penyusunan rencana tindakan, pelaksanaan tindakan, observasi tindakan dan refleksi.

Siklus I akan dimulai dengan perencanaan, pelaksanaan, pengamatan dan refleksi. Apabila dalam tindakan kelas ini ditemukan kekurangan dan tidak terpenuhinya target yang telah ditentukan, maka diadakan perbaikan pada siklus berikutnya. Penelitian tindakan kelas ini dilaksanakan di Sekolah Dasar Negeri 20 Mambok tahun pelajaran 2018/2019 dengan jumlah siswa 28 orang. Alat pengumpul data yang digunakan dalam penelitian ini yaitu a) lembar Observasi, b) Lembar tes c) Angket dan d) Dokumentasi.

Siklus I akan berhenti apabila sudah memenuhi kriteria sebagai berikut : 1) penggunaan pembelajaran Contextual Teaching and Learning mencapai $75 \%$ kategori cukup, 2) pemahaman konsep siswa KKM 70 dalam kategori cukup dengan ketuntasan klasikal 85\%, 3) respon siswa dalam mengikuti proses pembelajaran $75 \%$ dalam kategori cukup. Apabila siklus I belum memenuhi kriteria maka siklus akan berlanjut ke siklus II.

\section{HASIL DAN PEMBAHASAN}

Pelaksanaan

Pembelajaran

Contextual Teaching and Learning untuk Meningkatkan Pemahaman Konsep Operasi Hitung Perkalian dan Pembagian Siswa Kelas III C SDN 20 Mambok Tahun Pelajaran 2018/2019

Selama proses mengajar terdapat 7 komponen pembelajaran CTL yang menjadi acuan dalam melaksanakan pembelajaran. Adapun komponen-komponen Contextual Teaching and Learning yaitu: kontruktivisme (constructivism), menemukan (inquiry), bertanya (questioning), masyarakat belajar (learning community), pemodelan (modeling), refleksi (reflection), penilaian yang sebenarnya (authentic assessment). Hasil observasi aktivitas guru dan siswa disajikan pada Gambar 2 dan Gambar 3 sebagai berikut. 


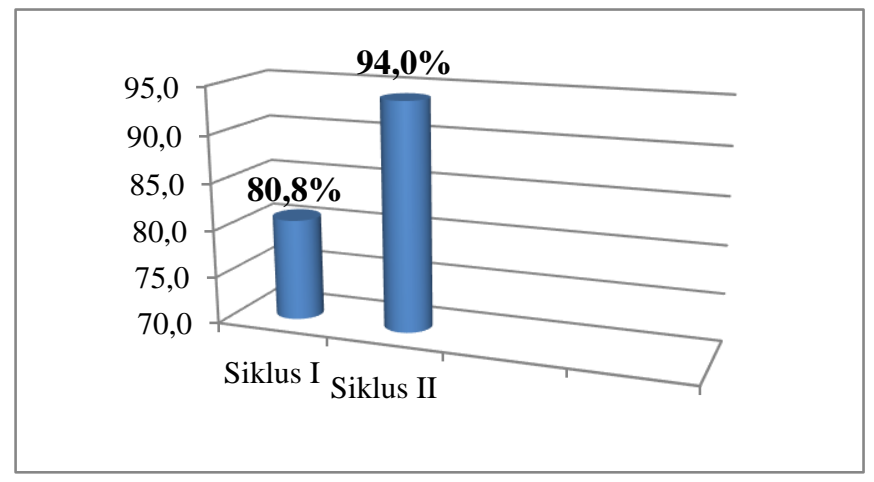

Gambar 2 Hasil Observasi aktivitas guru siklus I dan Siklus II

Hasil observasi aktivitas guru pada siklus I diperoleh rerata sebesar 80,8\% dengan kategori sangat baik. Sedangkan pada siklus II diperoleh rerata sebesar $94,0 \%$ dengan kategori sangat baik. Aktivitas yang dilakukan siswa dalam pembelajaran Contextual Teaching and Learning memfasilitasi siswa untuk terlibat aktif dalam menyelesaikan masalah matematis yang berkaitan dengan kehidupan sehari-hari berdasarkan komponen CTL. Hal ini sejalan dengan pernyataan Hardiawan (2013: 63) yang mengatakan bahwa pendekatan kontekstual merupakan pembelajaran yang menekankan keterlibatan siswa setiap tahapan pembelajaran dengan cara menghubungkannya dengan kehidupan sehari- hari sehingga pemahaman materi diterapkan dalam kehidupan nyata.

Peran guru pada pembelajaran CTL juga sanggat penting untuk mengarahkan siswa, sehingga siswa mampu berpikir, mampu menyampaikan ide, konsep atau gagasannya, dan secara kritis mampu menganalisis sendiri apa yang sudah disusunnya. Pembelajaran CTL mengutamakan keaktifan siswa.mengarahkan, oleh sebab itu guru harus mampu mempersiapkan perangkat pembelajaran yang mampu memfasilitasi siswa untuk mengeksplor kemampuan siswa.

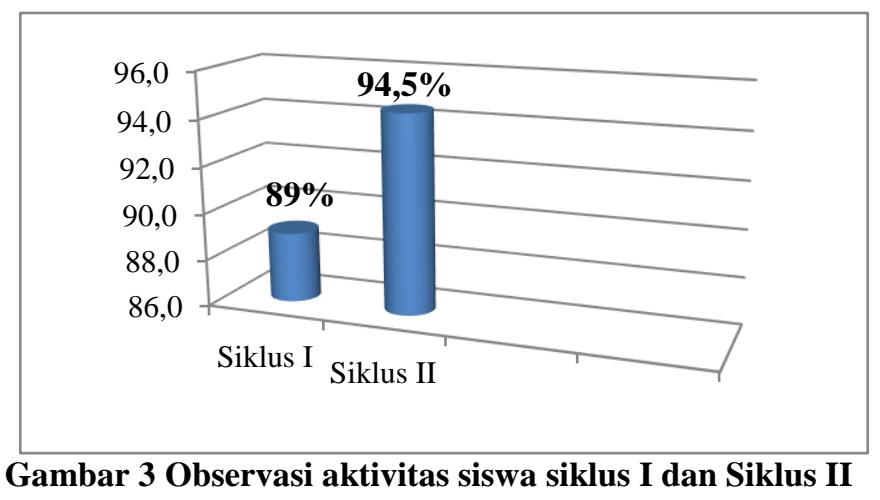

Berdasarkan observasi yang telah dilakukan pada siklus I sampai siklus II, kegiatan siswa dalam mengikuti pembelajaran menggunakan pembelajaran Contextual Teaching and Learning pada materi operasi hitung perkalian dan pembagian mengalami 
peningkatan dan dapat dikatakan sangat baik. Hal tersebut terlihat dari pengolahan data pada siklus I diperoleh rerata sebesar $89 \%$. Sedangkan siklus II diperoleh rerata sebesar 94,5\% dengan kategori sangat baik. Aktivitas guru sangat mempengaruhi aktivitas siswa dalam mengikuti pembelajaran. Tugas guru adalah membantu siswa mencapai tujuannya, maksudnya guru lebih banyak berurusan dengan strategi daripada memberi informasi. (Fitrah, 2016: 71).

\section{Peningkatan Pemahaman Konsep Operasi}

Hitung Perkalian dan Pembagian Siswa

Menggunakan Pembelajaran Contextual

Teaching and Learning di Kelas III C SDN

20 Mambok Tahun Pelajaran 2018/2019

Ulia (2017: 57) mejelaskan bahwa "Pemahaman konsep merupakan tingkatan hasil belajar siswa sehingga dapat mendefinisikan, menjelaskan sebagian atau mendefinisikan bahan pelajaran dengan menggunakan kalimat sendiri”. Dengan kemampuan siswa menjelaskan atau mendefinisikan, maka siswa tersebut telah memahami konsep atau prinsip dari suatu pelajaran meskipun penjelasan yang diberikan mempunyai susunan kalimat yang tidak sama dengan konsep yang diberikan tetapi maksudnya sama. Indikator pemahaman konsep yang digunakan dalam penelitian ini yaitu 1) Kemampuan menyatakan ulang sebuah konsep; 2) Kemampuan memberi contoh dan bukan contoh, dan 3) Kemampuan menyajikan konsep dalam berbagai bentuk representasi matematika. Peningkatan rata-rata tiap indikator pemahaman konsep siklus I dan siklus II disajikan pada Gambar 4 berikut.

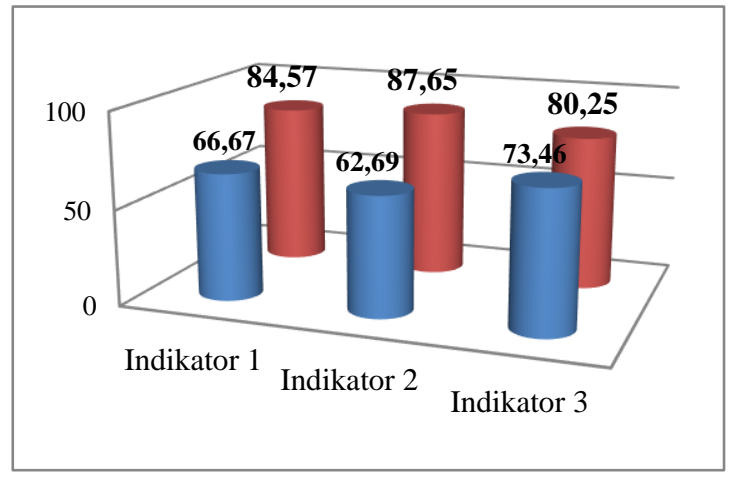

Gambar 4 Peningkatan Rata-rata Skor Pada Tiap Indikator Pemahaman Konsep

Indikator I siklus I diperoleh hasil rata-rata nilai sebesar 66,67 dengan kategori cukup. Meningkat pada hasil tes siklus II diperoleh hasil rata-rata nilai sebesar 84,57 dengan kategori sangat baik. Indikator II siklus I diperoleh hasil rata-rata nilai sebesar 62,69 dengan kategori cukup. Meningkat pada hasil tes siklus II diperoleh hasil rata-rata nilai sebesar 87,65 dengan kategori sangat baik. Indikator III siklus I diperoleh hasil rata-rata nilai sebesar 73,46 dengan kategori baik. Meningkat pada hasil tes siklus II diperoleh hasil rata-rata nilai sebesar 80,25 dengan kategori sangat baik.

Pada Prinsip pembelajaran CTL adalah aktivitas siswa, siswa melakukan dan mengalami, tidak hanya menonton dan mencatat, dan pengembangan kemampuan sosialisasi. Hal ini sejalan dengan Rusman (2012: 66) menjelaskan bahwa "Pendekatan 
kontekstual, mengajar bukanlah transformasi pengetahuan dari guru kepada siswa dengan menghapal sejumlah konsep-konsep yang sepertinya terlepas dari kehidupan nyata, akan tetapi ditekankan pada upaya memfasilitasi siswa untuk mencari kemampuan bias hidup (life skill) dari apa yang dipelajarinya".

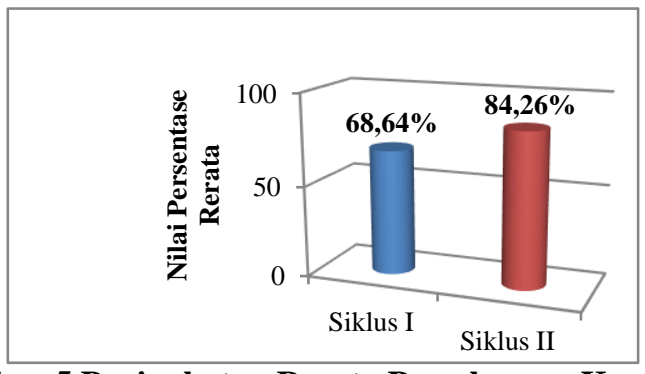

Gambar 5 Peningkatan Rerata Pemahaman Konsep Siswa

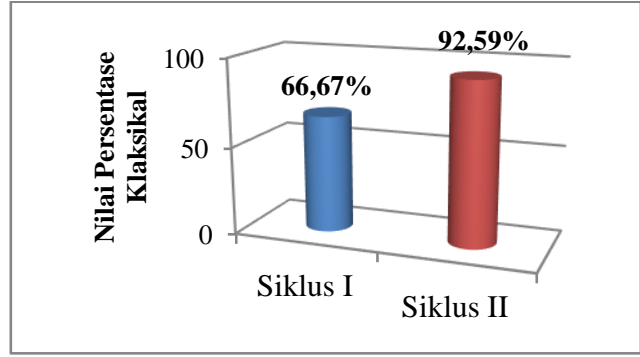

Gambar 6 Peningkatan Presentase Klaksikal Pemahaman Konsep Siswa

Pemahaman konsep operasi hitung perkalian dan pembagian siswa secara umum menunjukkan bahwa terjadi peningkatan dari siklus I ke siklus II. Berdasarkan hasil tes yang diperoleh, diketahui pada siklus I nilai ratarata siswa sebesar 68,64 dengan jumlah siswa yang dinyatakan tuntas sebanyak 18 siswa, dengan persentase $66,67 \%$. Sedangkan siswa yang tidak tuntas berjumlah 9 siswa dengan persentase $33,33 \%$. Kemudian pada siklus II, jumlah siswa yang dinyatakan tuntas berjumlah 25 siswa, dengan persentase $92,59 \%$. Sedangkan siswa yang tidak tuntas berjumlah 2 siswa, dengan presentase $7,41 \%$. Penelitian ini sudah mencapai target maksimal dan dinyatakan berhasil karena peningkatan jumlah siswa yang tuntas (masuk dalam kategori mencapai target sesuai KKM) sudah mencapai $85 \%$ dengan peningkatan sebesar $25,92 \%$.
Respon Siswa terhadap Penerapan Pembelajaran Contextual Teaching and Learning Pada Materi Operasi Hitung Perkalian dan Pembagian di Kelas III C SDN 20 Mambok Tahun Pelajaran 2018/2019

Berdasarkan hasil angket terhadap pembelajaran Contextual Teaching and Learning terlihat respon siswa terhadap penggunaan pembelajaran Contextual Teaching and Learning sangat baik. Angket respon siswa telah dibagikan kepada siswa sebanyak 15 nomor. Secara keseluruhan diperoleh hasil respon siswa terhadap penggunaan pembelajaran Contextual Teaching and Learning, nilai jawaban pernyataan siklus I sebesar 1426 jika dipersentasekan sebesar 95,1\%, sedangkan pada siklus II nilai jawaban penyataan sebesar 1489 jika dipresentasekan sebesar 99,3\%. 
Hasil persentase angket respon siswa pada siklus I menunjukkan bahwa respon siswa dalam kategori sangat baik tetapi terdapat beberapa item yang belum terlaksana secara maksimal sedangkan pada siklus II respon siswa sudah memenuhi kriteria ketuntasan yakni diatas $75 \%$. Adapun hasil angket respon siswa siklus I dan siklus II disajikan pada Gambar 7 dan Gambar 8 berikut.

Gambar 7 Respon Siswa Terhadap Penerapan Pembelajaran Contextual Teaching and Learning Siklus I

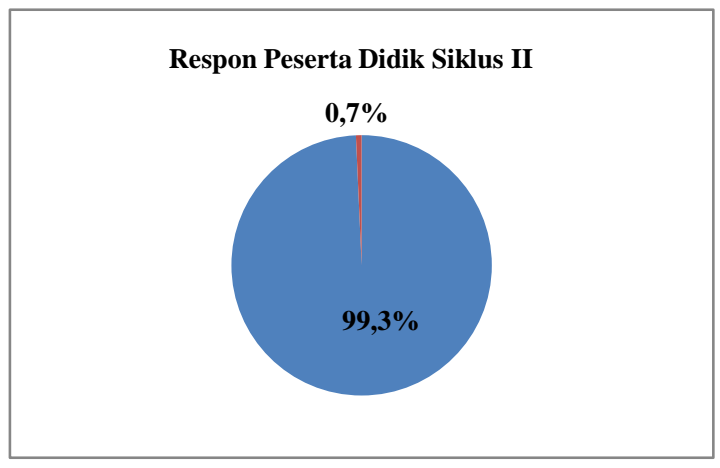

Gambar 8 Respon Siswa Terhadap Penerapan keseluruhan menunjukkan Pembelajaran Contextual

\section{Teaching and Learning Siklus II}

Hasil penelitian secara bahwa siswa memberikan respon yang positif dan tanggapan sangat baik terhadap penerapan pembelajaran Contextual Teaching and Learning. Hal tersebut ditunjukkan dengan rekapitulasi total angket respon siswa dalam kriteria sangat baik dengan jumlah sebesar 97,2\%. Menurut Komalasari (2014:7) pendekatan pembelajaran kontekstual merupakan pendekatan pembelajaran yang mengaitkan antara materi yang dipelajari dengan kehidupan nyata siswa sehari-hari, baik keluarga, sekolah, masyarakat maupun warga negara, dengan tujuan untuk menemukan makna materi tersebut bagi kehidupannya. Hal ini terlihat selama proses pembelajaran siswa sangat aktif dalam belajar dan didukung hasil angket respon yang telah diisi siswa setelah belajar menggunakan pembelajaran Contextual Teaching and Learning.

\section{SIMPULAN (PENUTUP)}

Berdasarkan hasil penelitian dan pembahasan dari tindakan kelas yang dilakukan seraca kolaboratif antara peneliti 
dengan guru wali kelas III C SDN 20

Mambok, didapat kesimpulan bahwa proses pembelajaran matematika

dengan

menggunakan pendekatan Contextual

Teaching and Learning (CTL) dapat meningkatkan pemahaman konsep siswa. Proses pembelajaran CTL selalu melibatkan tujuh komponen utamanya, tetapi pada pelaksanaannya beberapa komponen dapat dilakukan secara bersamaan, seperti komponen konstruktivis dan bertanya, inkuri dan masyarakat belajar, serta refleksi dengan penilaian sebenarnya.

Menggunakan pendekatan Contextual Teaching and Learning (CTL) dapat meningkatkan pemahaman konsep matematika siswa pada materi operasi hitung perkalian dan pembagian. Hal ini terlihat dari perolehan hasil belajar siswa pada siklus I diperoleh nilai tertinggi 80 dan nilai terendah 47 terjadi peningkatan pada siklus II dengan nilai tertinggi 100 dan nilai terendah 33. Pada siklus I nilai rata-rata kelas 68,64 dengan ketuntasan klasikal dalam belajar 66,67 \% siklus II ratarata kelas meningkat menjadi 84,26 dengan ketuntasan klasikal dalam belajar 92,59\%. Dari hasil siklus, nilai rata-rata meningkat sebesar 15,62 dan ketuntasan klasikal meningkat sebesar $25,92 \%$.

Respon siswa terhadap penerapan pembelajaran Contextual Teaching and Learning menunjukkan respon yang sangat baik. Hal tersebut terbukti dari persentasi jumlah siswa menjawab item pernyataan pada Siklus I sebesar $95,1 \%$ dan siklus II sebesar 99,3\%. Maka dapat disimpulkan respon siswa sangat baik dikarenakan pembelajaran Contextual Teaching and Learning sangat menyenangkan sehingga membuat siswa termotivasi dalam belajar.

\section{DAFTAR PUSTAKA}

Dafril, A. 2011. Pengaruh Pendekatan Konstruktivisme Terhadap Peningkatan Pemahaman Matematika Siswa. Makalah disajikan dalam Seminar Nasional.(Online).https://eprints.un sri.ac.id, diakses pada 4 November 2018.

Fitrah, M. 2016. Model Pembelajaran Matematika Sekolah Kajian Perspektif Berdasarkan Teori Dan Hasil Riset. Malang: CV. Budi Utama.

Hamzah, B Uno dkk. 2012. Assessment Pembelajaran. Jakarta: Bumi Aksara.

Hardiawan. 2013. Penggunaan Model Contextual Teaching And Learning (CTL) Sebagai Upaya untuk Meningkatkan Minat dan Kemampuan Pemahaman Konsep Garis dan Sudut pada Siswa Kelas VII MTs. Putra Nurul Hakim Kediri Tahun Pelajaran 2012/2013. Jurnal Lensa Kependidikan Fisika. Mataram: PKPSM IKIP Mataram. (ojs.ikipmataram.ac.id, diakses pada 10 Maret 2018).

Komalasari, K. 2014. Pembelajaran Kontekstual Konsep dan Aplikasi. Bandung: PT. Refika Aditama.

Rismawati, M. 2016. Analisis Kesalahan Koneksi Matematis Siswa Kelas X pada Materi Sistem Persamaan Linier Dua Variabel.Makalah disajikan dalam Konferensi Nasional Penelitian Matematika dan Pembelajarannya I, Surakarta.(Online).https://publikasi ilmiah.ums.ac.id/bitstream/handle/1 
1617/6951/13_103_Makalah\%20R ev\%20Melida\%20Rismawati.pdf?s equence $=1 \&$ is Allowed $=y$, diakses pada pada 26 November 2018

Rismawati, M., dkk. Struktur Koneksi Matematis Siswa Kelas X Pada Materi Sistem Persamaan Linier Dua Variabel. Jurnal Pendidikan: Teori, Penelitian, dan Pengembangan. 2(4):465-469, (Online), (http://journal.um.ac.id/index.php/j ptpp/, diakses 21 November 2018.

Rusman. 2012. Model-Model Pembelajaran Berbasis Teknologi Informasi dan Komunikasi. Jakarta: Rajawali Pers.

Sanjaya, W. 2011. Strategi Pembelajaran Berorientasi Standar Proses Pendidikan. Jakarta: Kencana.

Sugiyanto. 2009. Model-model Pembelajaran inovatif. Surakarta : Panitia Sertifikasi Guru Rayon 13.

Sugiyono. 2014. Memahami Penelitian Kualitatif. Bandung: Alfabeta.

Ulia, N. 2017. Peningkatan Pemahaman Konsep Matematika Materi Bangun Datar dengan Pembelajaran Kooperatif Tipe Group Investigation dengan Pendekatan Saintifik di SD. Jurnal Bina Bangsa.2(2):55-68. (Online), (htpp://research.unissula.ac.id diakses pada 4 November 2018.

Wulan, D.N. 2013. Penerapan Pendekatan CTL Untuk Meningkatkan Hasil Belajar Peserta Pdidik Pada Materi Bilangan Pecahan". Jurnal Antologi PGSD Bumi Siliwangi. 1(1):1-10. (Online), (htpp://antologi.upi.edu, diakses pada 16 Februari 2018. 